\title{
CORRECTION
}

\section{Correction: Clostridium difficile outcomes difficult to generalize}

Naresh Nagella, Kheng-Jim Lim and Amay Parikh

See related Letter by Nagella et al., http://ccforum.com/content/17/1/415

After publication of this letter [1], the authors noticed that the author name Khenj-Jim Lim should instead be stated as Kheng-Jim Lim.

\section{Competing interests}

The authors declare that they have no competing interests.

Published: 15 Jan 2014

\section{Reference}

1. Nagella N, Lim K, Parikh A: Clostridium difficile outcomes difficult to generalize. Crit Care 2013, 17:415.

\section{$10.1186 /$ cc13698}

Cite this article as: Nagella et al: Correction: Clostridium difficile outcomes difficult to generalize. Critical Care 2014, 18:402

\footnotetext{
*Correspondence: nagellna@umdnj.edu

Pulmonary and Critical Care Division, Department of Medicine, Robert Wood Johnson Medical School, 1 Robert Wood Johnson Place, P.O. Box 19, New Brunswick, NJ 08903-0019, USA
} 